\title{
Perspectivas do planejamento regional do Vale do Paraíba e litoral norte: marcos históricos e a institucionalização da região metropolitana no Plano de Ação da Macrometrópole Paulista
}

\author{
Perspectives of the Regional Planning of Paraiba Valley and North Coast: \\ Milestones and Institutionalization of the Metropolitan Region in the Action Plan \\ of the Macro-metropolis of São Paulo
}

Cilene Gomes, Paulo Romano Reschilian, Agnes Yuri Uehara

Universidade do Vale do Paraíba (UNIVAP), São José dos Campos, SP, Brasil

\section{Resumo}

\section{Abstract}

0 artigo traz uma releitura da história do planejamento regional centrado no Vale do Paraíba e Litoral Norte paulista, e nos principais estudos e planos desenvolvidos a partir dos anos 1940. Com essa proposta, o recente período histórico pôde ser mais bem situado em relação à institucionalização da região metropolitana (2012), ao Plano de Ação da Macrometrópole Paulista (2014) e ao Estatuto da Metrópole (2015), e apontamentos para discussões foram trazidos a caminho da elaboração do Plano de Desenvolvimento Urbano Integrado (PDUI). Assim, os debates em curso a respeito do referido novo plano regional (metropolitano) tendem a se tornar mais qualificados para fazer valer uma visão crítica e novos posicionamentos concernentes à contradição histórica de nossos dias, dispondo, lado a lado, a tendência ao planejamento pretendido para validação de um projeto hegemônico reforçador de disparidades socioterritoriais e o provável movimento de novos agentes pleiteadores de processos participativos consistentes e justiça social.

Palavras-chave: Planejamento regional. Regiões metropolitanas. Participação social. PDUI.

This article presents a reinterpretation of the history of the regional planning centered in the Paraiba Valley and North Coast of São Paulo and in the main studies and plans developed since the 1940s. With this proposal, the recent historical period could be better placed in relation to the institutionalization of the metropolitan area (2012), the Action Plan of the Macro-metropolis of São Paulo (2014), and the Statute of the Metropolis (2015), and issues to be discussed were raised with the preparation of the Integrated Plan for Urban Development (PDUI). Thus, the ongoing debates regarding the drafting of the new regional plan (metropolitan) become more qualified to enforce a critical view and questions concerning the current historical contradiction, featuring side

\footnotetext{
CG é docente pesquisadora do Programa de Pós-graduação em Planejamento Urbano e Regional da Universidade do Vale do Paraíba, graduação em Arquitetura e Urbanismo pela FAU-USP, doutorado em Geografia Humana pela FFLCHUSP, e-mail: cilenegomes2011@gmail.com

PRR é docente pesquisador/coordenador do Doutorado em Planejamento Urbano e Regional da Universidade do Vale do Paraíba, arquiteto e urbanista/bacharel em história, doutorado em Arquitetura e Urbanismo pela FAUUSP, pós-doutorado em Ciências Sociais PUC-SP, e-mail: pauloromano@univap.br

AYU é doutoranda em Planejamento Urbano e Regional pela Universidade do Vale do Paraíba, graduação em Arquitetura e Urbanismo na UEM, mestre em Planejamento Urbano e Regional da Universidade do Vale do Paraíba, e-mail: agyuri@hotmail.com
} 
by side, the tendency of the planning required for the validation of a reinforced hegemonic project of social and territorial disparities and the upward movement of new agents for consistent participatory processes and social justice.

Keywords: Regional planning. Metropolitan areas. Social participation. PDUI.

\section{Introdução}

Todo problema de planejamento é antes um problema da história territorial. As revisões históricas do planejamento urbanorregional são indicativas de transformações de cidades e regiões, dos aportes teóricos e das normas e diretrizes de ação que o definem. A releitura histórica do espaço urbanorregional do Vale do Paraíba paulista e seu planejamento, dos anos 1940 e 1950 até hoje, será feita aqui, objetivando melhor circunstanciar a retomada do planejamento regional, em 2012, com a institucionalização da Região Metropolitana do Vale do Paraíba e Litoral Norte (RMVPLN).

A escolha do tema justifica-se pela necessidade e importância da reconstrução de embasamentos para compreender o fenômeno metropolitano e regional, e a participação ativa nos debates atuais sobre o desenvolvimento planejado da RMVPLN, considerando-se o Estatuto da Metrópole (Brasil, 2015) e o Plano de Ação da Macrometrópole Paulista (PAM) (EMPLASA, 2014), a caminho do Plano de Desenvolvimento Urbano Integrado (PDUI).

Pressupondo-se a instrumentalidade do processo de metropolização do espaço para a sustentação da globalização econômica e tecnológica, por meio da integração técnico-econômica do território (Silva, 2002) e da aceleração de transformações socioterritoriais para o mercado, os rumos do planejamento regional e do desenvolvimento do Vale do Paraíba e Litoral Norte constituem séria preocupação.

Será o PAM apenas uma retradução de orientações políticas e do planejamento urbano e regional desenvolvidos "de cima para baixo", ao longo da história, pela União e pelo Estado de São Paulo? Se a formação da Macrometrópole Paulista (MMP) remonta aos anos 1950 e condiz com a reorganização do espaço metropolitano da capital paulista orientada pela irradiação da industrialização para o interior e o litoral do Estado, indaga-se sobre a possibilidade de rupturas com projetos político-territoriais criadores de privilégios e desigualdades socioespaciais.

Quais as perspectivas de reorientação do atual processo de planejamento da RMVPLN, dadas as normativas de ampla participação da sociedade e cooperação interfederativa? Que embates e conciliações o PAM suscitará durante a elaboração do PDUI da RMVPLN?

Uma das suposições do artigo reside na tendência à remodelação do espaço urbanorregional do Vale do Paraíba e Litoral Norte, à luz das diretrizes do PAM, sem as devidas considerações acerca da dialética global-local, subentendendo a indispensável liderança paulista, em detrimento da construção de um projeto de nação, social e territorialmente abrangente (Reschilian \& Uehara, 2015). No caso, as regiões metropolitanas do Vale do Paraíba e Litoral Norte, Sorocaba e Ribeirão Preto seriam tomadas como "peças faltantes" do mosaico territorial da Macrometrópole - a principal unidade de planejamento do governo estadual.

Contraditoriamente, entende-se que não se pode supor a supremacia absoluta do pensamento único (Santos, 2000), inerente ao projeto de globalização econômica, que tenta se impor a todo custo e, tampouco, subestimar a ordem local, ou seja, a natureza dinâmica dos sistemas socioespaciais locais, a inteligência e a capacidade de autorregulação local (Bicudo, 2009) dos processos e práticas sociais intrínsecos ao local. Por isso, também se afirma a hipótese da tendência à ascensão progressiva de novas forças de microssocialização e manifestação dos cidadãos, mais equiparáveis às forças do Estado.

Na incursão retrospectiva da primeira seção do artigo, as transformações da região valeparaibana serão consideradas convergindo à intensificação da urbanização ao redor dos eixos Dutra e litorâneo, e, assim, a uma organização socioeconômica correlata à desatenção do Estado relativamente a outras porções do espaço regional, levando a defasagens e disparidades no desenvolvimento. Paralelamente, optou-se pela reconstituição do planejamento regional, 
representado pelos planos e diagnósticos elaborados desde os anos 1940. Tal opção levou a destacar, para melhor entendimento e avaliação objetiva da situação atual, os agentes envolvidos na elaboração dos planos e estudos; os marcos regulatórios e concepções do planejamento estatal; os objetivos, diretrizes eáreas de abrangência. Estabelecendo-se conexão com a segunda seção, encadeou-se a trajetória recente de retomada do planejamento regional (com a institucionalização da RMVPLN) ao atual, contraponto entre a existência do PAM e as normativas do Estatuto da Metrópole.

Na segunda seção, a remodelação do espaço urbanorregional do Vale do Paraíba e Litoral Norte será cotejada à formação da Macrometrópole paulista, a proposições do PAM e apontamentos para discussão no percurso de elaboração do PDUI, a respeito de preocupações e perspectivas ligadas à contradição perceptível entre a prevalência de um planejamento praticamente imposto e a provável dinâmica de associações e participação de agentes locais, que poderá se ampliar e fortalecer, engendrando o indispensável debate social sobre o desenvolvimento regional e seu planejamento.

\section{Retrospectiva histórica do planejamento regional do Vale do Paraíba e litoral norte}

O potencial de interconexão geográfica do Vale do Paraíba, por sua localização entre o litoral e interior do Estado paulista e duas metrópoles nacionais, tem sido apontado como um dado relevante do processo de ocupação, povoamento e urbanização regional (Figura 1). A própria dinâmica de desenvolvimento da complexa estrutura macrometropolitana paulista, em parte, por aí se define (EMPLASA, 2014).

No retrospecto à história dos primeiros séculos, é preciso ressaltar o papel indutor do Rio Paraíba do Sul e dos primeiros caminhos terrestres na formação territorial regional (Muller, 1969, p. 11 e 18), e já a partir da primeira metade do século XIX a meados do século XX, a rápida prosperidade regional advinda

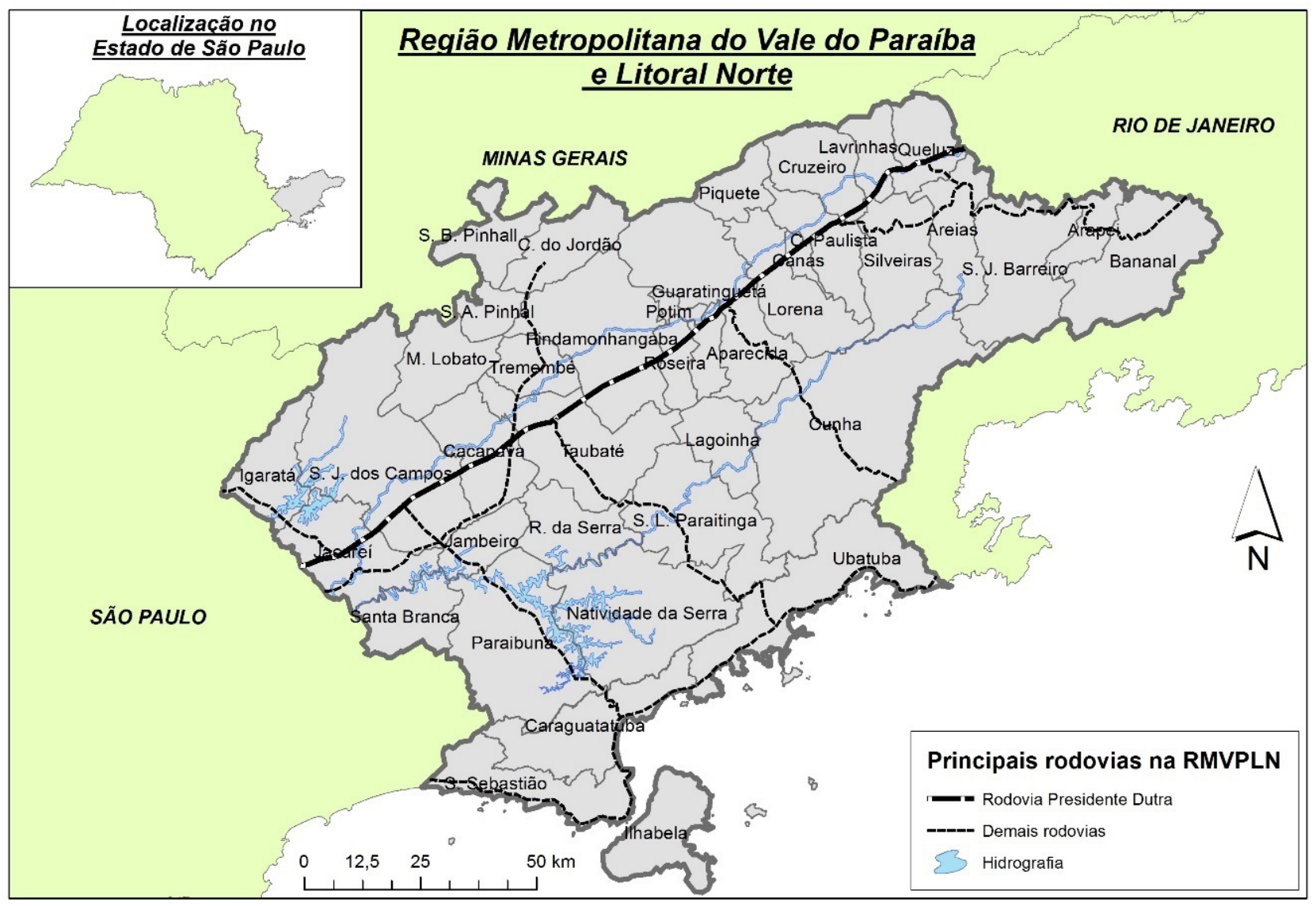

Figura 1 - Localização da Região Metropolitana do Vale do Paraíba e Litoral Norte Fonte: Elaboracão de Daniel José de Andrade - IBGE (2010); DNIT (2013). 
com a economia cafeeira e os novos ritmos de industrialização e urbanização.

No final da década de 1930, o equacionamento (pioneiro e sistemático) de problemas e diretrizes de planejamento regional, para o Vale do Paraíba, teve início com os estudos para o seu reerguimento econômico, realizados pelo Serviço de Melhoramento do Vale do Paraíba do Governo Adhemar de Barros, propondo avaliar as possibilidades de aproveitamento agrícola das várzeas (Figura 2) pelo controle das águas do Rio Paraíba, de drenagem e irrigação, e, ainda, de navegabilidade fluvial (Baptista, 1940, p. 38, 42-43).

Daí aos anos 1970, a região se transforma intensamente com a implantação da Rodovia Presidente Eurico Gaspar Dutra e uma estruturação industrial diversificada, ligada ao crescimento industrial da Grande São Paulo (Muller, 1969, p. 83), a migrações e ao êxodo rural, junto à expansão de comércios e serviços, com destaque às atividades técnico-científicas e profissionais especializadas do ramo da aeronáutica e defesa, e, depois, do complexo aeroespacial.

Ronca \& Vitale (2004, p. 141) enfatizam a lógica do desenvolvimento regional orientado pela perspectiva de integração nacional quase exclusivamente econômica e de equipamento rodoviário, interligando importantes cidades do país e promovendo acessibilidade física e desenvolvimento socioeconômico a territórios nacionais atrelados à industrialização. 0 planejamento estatal para a modernização do país conduz, de fato, à remodelação de novas bases produtivas e novos equipamentos regionais de integração territorial (porto, energia, comunicações), favoráveis à unificação local e ampliada do sistema produtivo e do mercado interno.

Este processo global também se rebate espacialmente pela urbanização regional intensificada e definida linearmente, ao longo do novo eixo viário, com dinâmicas urbanas diferenciadas pelas condições mesológicas particulares às principais cidades, crescendo em suas margens. Em Muller (1969, p. 116), pode-se visualizar a rede urbana do Vale do Paraíba na década de 1960 , por suas polarizações e hierarquias, definidas pela estrutura funcional e morfológica das diferentes cidades. Destacam-se, então, com maior poder de polarização espacial, os núcleos urbanos consolidados de Taubaté, São José dos Campos, Guaratinguetá e Cruzeiro.

As décadas de 1960 e 1970 constituem um período de organização e consolidação do planejamento estatal

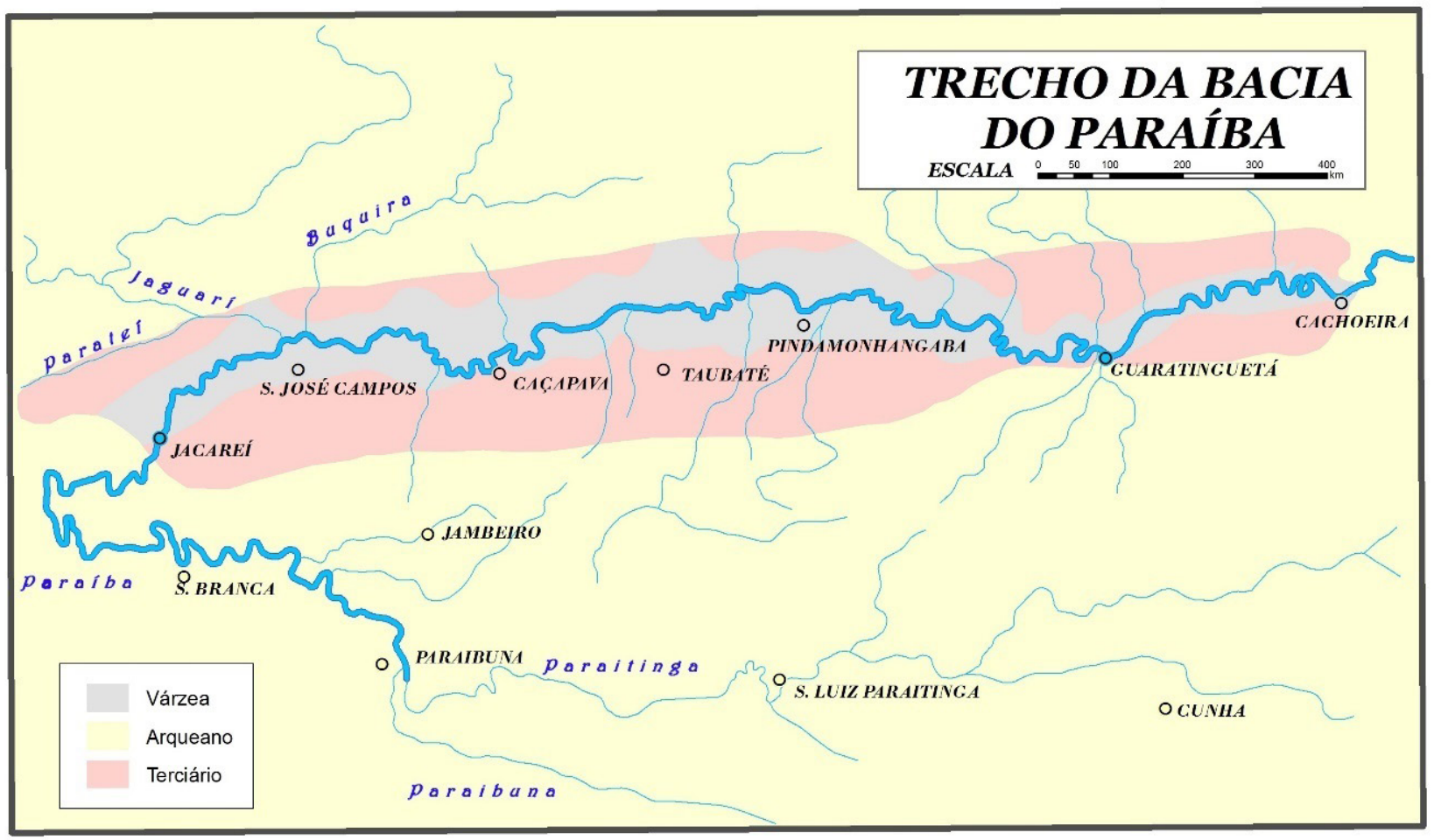

Figura 2 - Várzea do Rio Parába do Sul

Fonte: Adaptado de Baptista (1940, p. 26). 
no país, impulsionado por empréstimos internacionais, regime militar e disciplinamento, estabelecido pela Constituição de 1967/69 (Brasil, 1969). Sob estas condições e com limitação da autonomia estadual e municipal, dizem Silva et al. (2002, p. 6), tornou-se possível uma articulação das medidas de planejamento implantadas nas três instâncias de governo, possibilitando o planejamento na dimensão regional articulado com a escala federal, as "regiões de desenvolvimento" e, na estadual, as "regiões administrativas".

Na busca de coordenação governamental, atos normativos e um sistema de planejamento implantado levaram à modernização da administração pública. Com destaque para o Estado paulista e o planejamento no Vale do Paraíba e Litoral Norte, o ponto de partida foi a Lei 8.208/1964 (São Paulo, 1964), criando a Secretaria de Estado dos Negócios de Economia e Planejamento, e representando "a condição para que o Decreto 48.162/67 viabilizasse a “[...] regionalização da ação governamental e de seu planejamento", mediante institucionalização de regiões político-administrativas (Silva et al., 2002, p. 7).

Em 1970, com o Decreto 52.548 (São Paulo, 1970), promoveu-se a regionalização da estrutura administrativa da Secretaria de Economia e Planejamento. Conforme relatam ainda Silva et al. (2002, p. 10), criou-se um órgão para conduzir a política regional do Estado, a Coordenadoria de Ação Regional (CAR), com a função de elaborar os “[...] documentos técnicos, diagnósticos e análises regionais que embasaram, na época, as políticas de desenvolvimento regional do governo". Também foram criados os Escritórios Regionais de Planejamento (ERPLAN), para a "condução da política regional do governo nas respectivas áreas de abrangência".

Além do primeiro Plano Nacional de Desenvolvimento (PND) (1972/1974), mas igualmente em consideração a este, o período instaura a "[...] concepção técnico-científica da gestão territorial, até então limitada à gestão metropolitana" (Silva et al., 2002, p. 10), para o interior do Estado paulista. Em 1973, foram publicados 12 "Diagnósticos Regionais", compondo a base empírica dos "Planos Regionais" feitos entre 1976 e 1978, e dos programas implantados com a Política de Desenvolvimento Urbano e Regional (PDUR), de 1976, originados após o segundo PND (1975/1976).

Constituindo-se em uma experiência bem sucedida de planejamento regional no Estado de São Paulo, a PDUR incluía diretrizes para áreas de contenção, controle, disciplina e dinamização, e, ainda, programas governamentais de âmbito regional foram implantados: Cidades Médias, Macro-Eixo Rio-São Paulo, Macrometrópole, Desconcentração e Descentralização Industrial e Cidades Pequenas (Silva et al., 2002, p. 9).

Completando-se o panorama do planejamento estatal antes da Constituição Federal (CF) de 1988 (Brasil, 1988a), destacam-se mais dois atos normativos do período: a Lei Complementar Federal 14/1973 (Brasil, 1973), criando oito regiões metropolitanas brasileiras ${ }^{1}$, e a Lei Complementar 94/1974 (São Paulo, 1974), que cria a Empresa de Planejamento Metropolitana (EMPLASA). Nesse momento, "[...] o planejamento 'metropolitano' distancia-se do planejamento regional do 'interior'", descompondo a visão de conjunto da gestão territorial.

Associados à intensa dinâmica socioespacial urbana da região valeparaibana, na década de 1970, três importantes trabalhos do planejamento regional surgem como decorrência lógica da ideologia do planejamento estatal em franca propagação no âmbito nacional e estadual.

0 primeiro resultou no documento Caracterização e Avaliação dos Conhecimentos Existentes sobre a Região do Vale do Paraíba e Diagnósticos Resultantes, realizado, em 1971, pelo Consórcio de Desenvolvimento Integrado do Vale do Paraíba e Litoral Norte (CODIVAP), e equipe técnica contratada, que reúne conhecimentos e dados para uma visão global da região e dos municípios (Figura 3), segundo os eixos Ecológico, Urbanístico, Socioeconômico, Sociocultural e Institucional.

Trata-se de um diagnóstico regional para subsidiar a programação sistemática do planejamento integrado, incluindo proposições analíticas de conhecimentos sobre a região, e recomendações para a ação independentes de estudos específicos para implementação. Mostra-se interessante observar a menção de Paulo Egydio Martins $^{2}$, na apresentação do trabalho, do necessário trato comum de problemas entre municípios, da falta de apoio, recursos e interdependência dos poderes municipal, estadual e federal, e, ainda, a suposição

\footnotetext{
${ }^{1}$ São Paulo, Belo Horizonte, Porto Alegre, Recife, Salvador, Curitiba, Belém e Fortaleza, e, depois, a do Rio de Janeiro, que seria estabelecida pela Lei Complementar n.ํㅜ 20/75 (Brasil, 1975).

${ }^{2}$ Primeiro superintendente do CODIVAP e governador do Estado de São Paulo (1975-1979).
} 


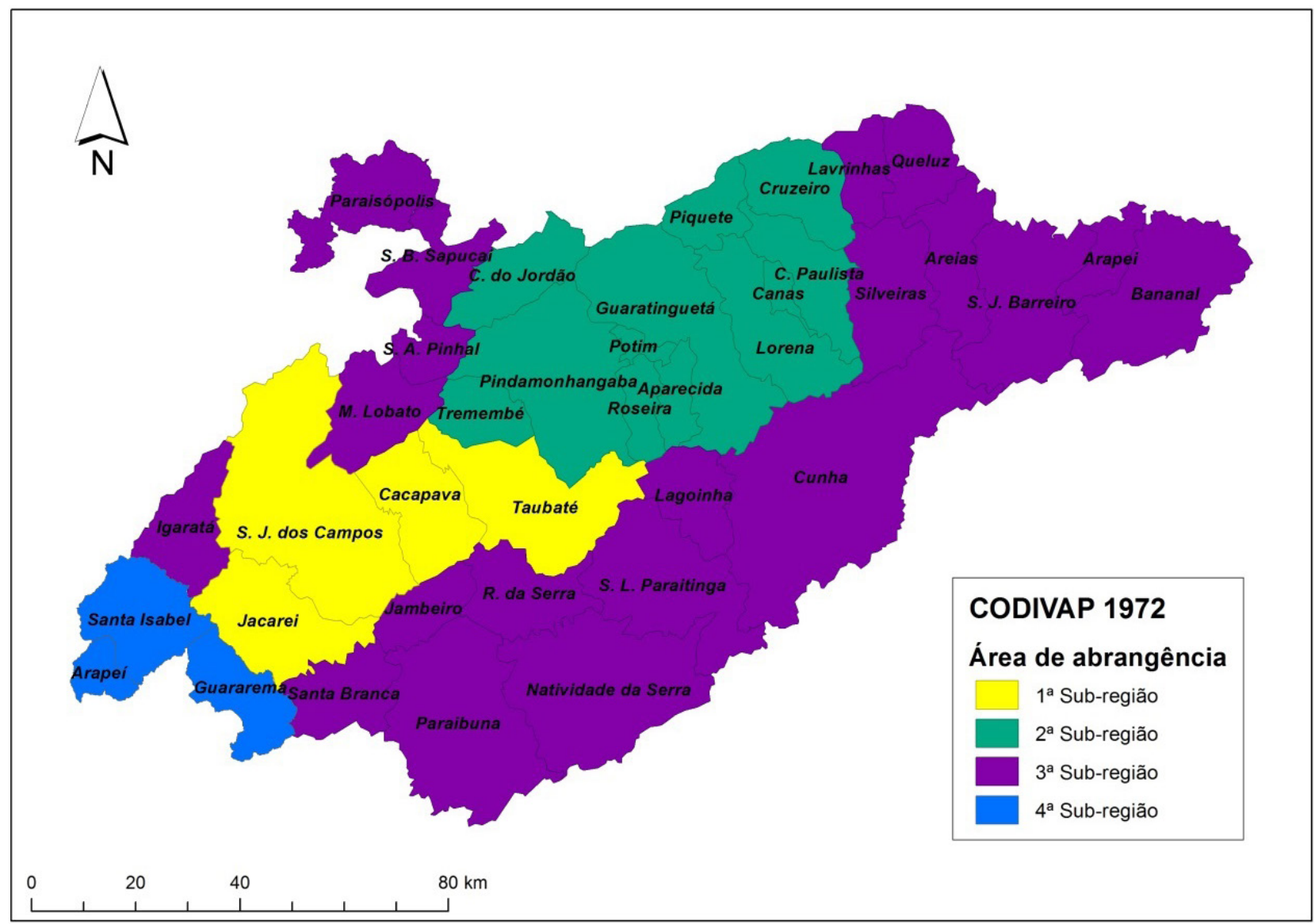

Figura 3 - Área de Abrangência da Região CODIVAP

Fonte: Elaboração de Daniel José de Andrade - CODIVAP (1971, p. 97).

de que a região tenderia a se constituir como uma só cidade.

Dentre outros aspectos relevantes para a visão de conjunto da região, destacam-se as análises da dinâmica urbana em relação à ocupação do solo e ao transporte, e, tendo em vista o progresso da urbanização e a política integrada, o objetivo de avaliar as polarizações e tendências a conurbações, e o "[...] enquadramento do Vale do Paraíba, no todo ou em partes, como áreas metropolitanas" (CODIVAP, 1971, p. 12-13).

Se a população urbana da região subiu de $37,9 \%$, em 1940, para 73,2\%, em 1970, a rápida urbanização se deu, todavia, de forma circunscrita aos municípios de urbanização já consolidada ao longo da Rodovia Dutra e a outros com tendência à dinamização industrial, como Jacareí e Caçapava.

Relacionado diretamente ao Plano Macro-Eixo Rio-São Paulo, o segundo trabalho de caráter regional foi o Plano Regional do Macro-Eixo Paulista, publicado em 1978, sob a direção do governador Paulo Egydio Martins, e, atuando na Secretaria de Economia e Planejamento, o arquiteto Jorge Wilheim. A área de abrangência deste plano, composta por 39 municípios situados entre a Grande São Paulo e o Estado do Rio de Janeiro, e estendendo-se da Serra da Mantiqueira ao litoral, foi dividida em cinco sub-regiões, conforme Figura 4.

Trata-se de um trabalho de análise e proposição orientado para atender à política de descentralização industrial, estabelecida pelo II PND e a PDUR, em razão do crescimento acelerado das metrópoles e do esvaziamento populacional das pequenas cidades, subentendendo ampla reestruturação da rede urbana regional. Dentre suas diretrizes, destacam-se: a coordenação de investimentos e a regulamentação do uso do solo; a contenção do crescimento metropolitano aliada à descentralização produtiva para centros de médio porte; planejar e disciplinar a urbanização da orla marítima, conciliando turismo, lazer e preservação ambiental (São Paulo, 1978, p. 2).

Buscando-se estabelecer uma política de desenvolvimento regional, o plano resulta de análises da 


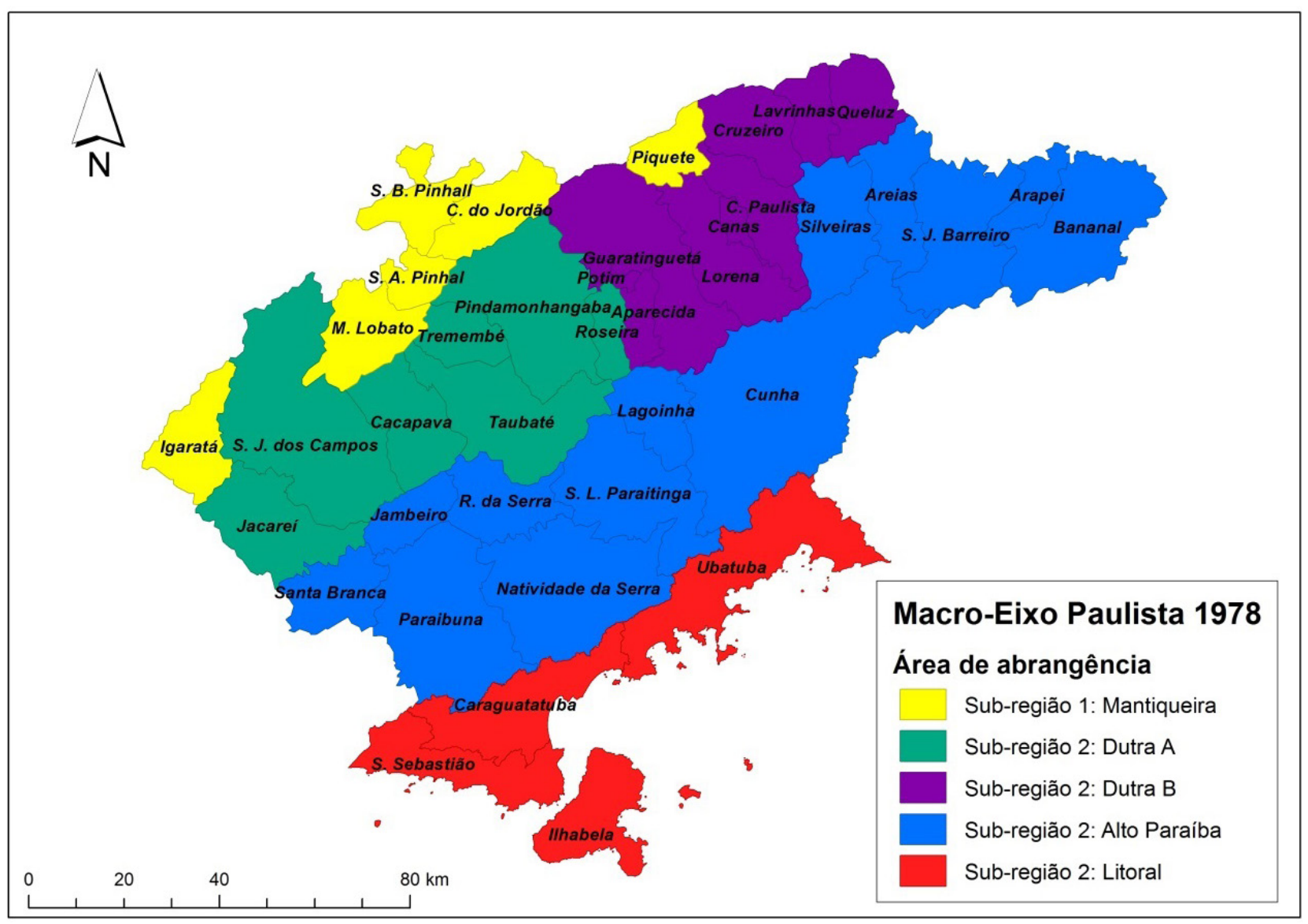

Figura 4 - Municípios e Sub-regiões do Macro-Eixo Paulista

Fonte: Elaboracạ̃o de Daniel José de Andrade - Governo do Estado de São Paulo (1978, p. 4).

história do desenvolvimento econômico e da organização territorial regional, direcionadas a caracterizações e diagnósticos das diferentes sub-regiões e municípios, com foco na ocupação espacial das áreas fora da Grande São Paulo, ao longo dos principais eixos viários, e no reconhecimento de desempenho econômico e potencialidades regionais diferenciadas.

Não se pode dissociar das ações do governo paulista e do Plano do Macro-Eixo, o Plano Regional do Litoral, também de 1978, inseridos ambos no quadro geral das determinações do planejamento estatal para a região.

0 terceiro trabalho considerado para reconhecer as ações planejadas na região intitula-se Diretrizes de ordenamento do Uso do Solo: Macrozoneamento da Bacia Hidrográfica do Rio Paraíba do Sul (CEEIVAP, 1979), realizado pelo Comitê Executivo de Estudos Integrados da Bacia Hidrográfica do Rio Paraíba do Sul (CEEIVAP), cuja importância liga-se à discussão mais ampla do planejamento regional, ao incorporar a questão ambiental enfatizando as "[...] ações preventivas de combate à degradação" (Coelho, 1998, p. 40-41).
De fato, sua contribuição reside na antecedência da iniciativa em vista das preocupações com a gestão dos recursos hídricos, as quais, no final dos anos 1990, voltarão à cena com o Plano Nacional de Recursos Hídricos (Brasil, 1997), para implementação em bacias de rios federais, como é o caso da Bacia do Paraíba do Sul, estendendo-se pelos Estados de São Paulo, Minas Gerais e Rio de Janeiro.

Transcorridos os anos de 1980 e 1990, a realidade regional mostra-se bastante transformada, agora com dois eixos de urbanização e desenvolvimento consolidados (Dutra e Litorâneo), conformando territórios representativos da desconcentração produtiva e demográfica, e da integração regional, em contraste com outras porções da região à margem das atenções do poder público e dos interesses privados.

Nesse período em que houve, após o movimento nacional pela Reforma Urbana, e junto à macrourbanização do território (Santos, 1993, p. 78), o novo "divisor de águas" da Política Urbana Brasileira, com a CF de 1988, quando a atribuição de instituir regiões 
metropolitanas passa aos Estados, demarcando nova etapa das políticas regionais no país.

Nesse contexto, em 1992, é produzido outro trabalho do planejamento regional, o Macrozoneamento do Vale do Paraíba e Litoral Norte do Estado de São Paulo-MAVALE, tratando-se este de um novo relatório técnico, resultante de convênio entre o Instituto de Pesquisas Espaciais (INPE) e o CODIVAP, nos quais, além dos tradicionais levantamentos, incluem-se informações obtidas com o uso de tecnologias do sensoriamento remoto - a grande ferramenta para a construção de visões sinópticas da realidade regional e, particularmente, do uso do solo, constituindo-se, assim, o novo recurso metodológico disponível, a partir de então, aos municípios e ao planejamento regional. Segundo o INPE (1992), os mapeamentos e análises dos meios físico, social e urbano do território regional (Figura 5) tinham, dentre outros objetivos, de avaliar a expansão urbana e identificar áreas de conflito de usos e com potencial risco ambiental, e, assim, embasar ou sugerir propostas de atividades adequadas frente às características e problemas apontados.

Devem ainda ser mencionados os diagnósticos e planos realizados desde 1997, no contexto da Política Nacional de Recursos Hídricos na Bacia do Rio Paraíba do Sul, “[...] quando se identificou a dimensão e a gravidade dos problemas de desmatamento e degradação dos solos e os consequentes impactos negativos para a quantidade e qualidade das águas" (AGEVAP, 2007, p. 1).

Por fim, constata-se, em 2004, outro marco da ação planejada regional, com o Zoneamento Ecológico-Econômico do Litoral Norte (São Paulo, 2004), instituído por meio do Decreto Estadual 49.215, decorrente do cumprimento da Lei Estadual do Gerenciamento Costeiro, e consoante aos princípios e diretrizes do Plano Nacional de Gerenciamento Costeiro - Lei 7.661, de 16 de maio de 1988 (Brasil, 1988b), com ênfase justamente no referido Zoneamento.

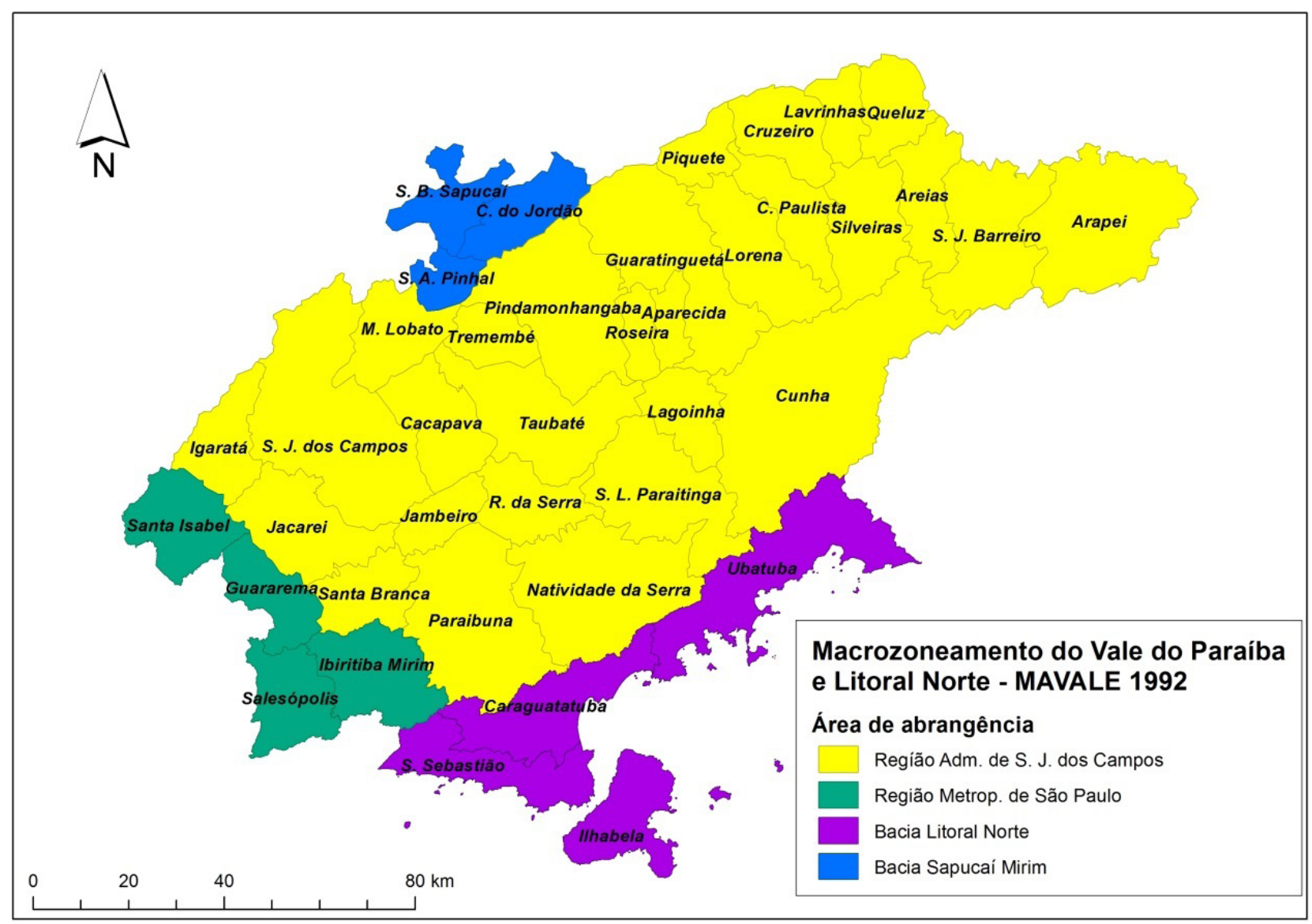

Figura 5 - Sub-regiões e municípios trabalhados no MAVALE Fonte: Elaboração de Daniel José de Andrade - INPE (1992, p. 5). 
Considerando-se o panorama apresentado e passados mais de 10 anos até 2016, uma síntese necessária para estabelecer conexões com a atualidade condiz com a retomada do planejamento regional e/ou metropolitano em escala nacional e estadual, sendo a institucionalização da RMVPLN o novo demarcador do processo, no âmbito local.

\section{A retomada do planejamento regional}

No âmbito do país, o planejamento estatal tende a se fortalecer até final dos anos 1970, fazendo prevalecer um modelo de desenvolvimento alinhado ao plano internacional. Passados os tempos de acirrada afirmação geopolítica, do regime militar e, com este, da planificação de fundo tecnoburocrático (e não participativo), chegou-se de fato a uma integração territorial e produtiva do país, mas sem que se lograsse êxito completo, pois, na busca de modernização, esta se mostra inalcançável e conservadora, mantendo a reprodução do atraso, com um nível de organização socioespacial pouco equilibrado e justo. No dizer de Maricato (2000), "as ideias fora do lugar" e "o lugar fora das ideias" terminaram configurando uma planificação regional e urbana que consagra a institucionalização de um estado forte e planos conduzidos para garantir infraestruturas e uma divisão social de trabalho sustentadora da reprodução do capital internacional.

A incidência deste processo global no plano regional se dá por meio de ações coordenadas entre governo nacional e estadual (paulista). A iniciativa do CODIVAP, de 1971, mesmo datada no referido período do planejamento nacional, pode ser entendida como experiência precursora de cooperação intermunicipal na região valeparaibana, antecedente aos reflexos regionais da planificação centralizadora dos governos militares, quando a autonomia municipal perde força. Com o tratamento mais sistemático da questão ambiental no âmbito governamental, o final dos anos 1970 demarca, também, a preocupação com a gestão de recursos hídricos e a repercussão na região com o CEEIVAP, um instrumento institucional com sobreposição de interesses federal e estaduais.

Nas décadas de 1980 e 1990, com o avanço das políticas neoliberais e de grandes agentes da globalização econômica, e, ainda que em pleno momento de reconstituição democrática, a ação estatal no planejamento regional e urbano torna-se menos visível.
Formulações para outro projeto de Estado/Nação não se efetivam em função de decisões, em escala global e nacional, dos pressupostos do Fundo Monetário Internacional e do Consenso de Washington, com receitas restritivas ao papel do Estado em países do capitalismo periférico. Na região, alternando a relativa ausência do planejamento estatal, dois agentes se destacam com a proposição de estudos para fins de planejamento, compondo o MAVALE: novamente o CODIVAP, agora aliado ao INPE, com seus modernos instrumentais tecnológicos, para análise territorial.

Todavia, desde os anos 2000, com as reorientações governamentais, as incursões do planejamento ambiental e as repercussões da CF de 1988, um novo período de retomada dos planejamentos estatal, regional e urbano, pôde de fato ser constatado. Nesse contexto, o Estatuto da Cidade (Lei n. ${ }^{\circ}$ 10.257/2001, Brasil, 2001) vem regulamentar os preceitos constitucionais da política urbana e a proliferação de regiões metropolitanas leva à aprovação do mais novo marco regulatório, a

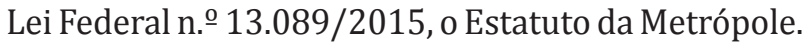
O Estado federal reassume sua função de estudar, planejar e normatizar o ordenamento territorial nas escalas nacional, regional e metropolitana, mas, agora, reconhecendo a autonomia dos municípios, a qual, todavia, deve ser ponderada em sua relatividade, diante das prescrições do novo estatuto metropolitano com respeito às funções públicas de interesse comum (metropolitano), à governança interfederativa e à ampla participação social.

À luz de tais postulados, a institucionalização da RMVPLN - Lei Complementar 1.166/2012 (São Paulo, 2012) e a Agência Metropolitana do Vale do Paraíba e Litoral Norte (AGEMVALE), criada pela Lei Complementar 1.258/2015 (São Paulo, 2015), carreiam o novo desafio do planejamento regional, de elaboração do PDUI, com um provável novo jogo de forças que, na perspectiva mais otimista, poderá promover a condução de um processo com aprimoramento de metodologias de cooperação e participação social.

Neste percurso, deve-se levar em conta a interposição do governo estadual paulista com a proposição do PAM. A integração da expansão metropolitana de São Paulo às dinâmicas regionais do interior do Estado paulista está na base da redefinição, após 1988, das novas unidades metropolitanas instituídas, as quais, supostamente, seriam "peças faltantes" do mosaico territorial para a pretendida unificação macrometropolitana e a validação do PAM, como 
grande balizador da força de liderança política e ideológica do Estado paulista.

\section{Remodelação do espaço urbanorregional à luz do plano macrometropolitano}

A retomada do planejamento regional estabelecida pela institucionalização da RMVPLN contrapõe ao PAM o curso dos acontecimentos, que confluirá para a elaboração do PDUI e futura remodelação do espaço urbano regional. Os entendimentos sobre a formação da Macrometrópole paulista e os conteúdos propositivos do PAM são fundamentais para melhor avaliar perspectivas e tendências de remodelação socioespacial regional, e reunir apontamentos para subsidiar debates e possível construção coletiva do planejamento regional.

\section{Formação da macrometrópole paulista}

Conforme o jornal O Estado de São Paulo (Penha, 1991), geógrafos e urbanistas batizaram de Macrometrópole o complexo urbano formado, desde o final da década de 1950, pela ligação de São Paulo com as regiões do Vale do Paraíba, Sorocaba, Baixada Santista e Campinas, por meio dos eixos rodoviários e da expansão da industrialização da Grande São Paulo.

Tal perspectiva integradora tornou-se explícita no trabalho do CODIVAP (1971), ao afirmar que a região se enquadraria, em parte, no contexto de áreas metropolitanas. De modo similar, o Plano do Macro-Eixo enunciava a proposta de identificar “[...] áreas prioritárias para a atuação do poder público e a localização de investimentos do setor privado, ambas visando o desenvolvimento integrado da Região" (São Paulo, 1978, p. 6).

A matriz da visão dos planejamentos nacional e regional, decorrente da ideia de ação política integrada, delineou-se pela indissociável relação com o fenômeno territorial, o qual, dos anos 1940 e 1950 aos anos 1970 e 1980, apontava justamente para a tendência a uma urbanização concentrada e de formação de metrópoles em poucos pontos do território - as capitais dos Estados - , tendo à frente a dinâmica urbano-metropolitana paulistana.

Por hipótese, a formação macrometropolitana de São Paulo teve seu desenho original esboçado desde meados do século XIX, por seu papel estruturador de uma configuração territorial de grande rede (Meyer et al., 2004), embora tenha sido efetivamente constituída pelo forte ímpeto de expansão da cidade de São Paulo, nos anos 1930 e 1940, a partir das expansões viárias para novos arruamentos e loteamentos, e da reserva de terras para futuros proveitos especulativos. É daí que se desencadeiam implantações em outras escalas de urbanização, com o agigantamento da estrutura metropolitana e uma força de espraiamento sem medida, levando à formação de extensas periferias (Meyer et al., 2004; Silva, 1990).

Dos anos 1950 aos 1980, a metrópole paulistana torna-se o epicentro da modernização em curso, no país. No âmbito das ações federal e estadual, surgem as políticas descentralizadoras e os planos que incidem territorialmente, levando à dimensão macrometropolitana de São Paulo, onde os sistemas viários e demais sistemas de integração territorial funcionam como "extensores de expansão" (Silva, 1990). Trata-se da expansão da região concentrada para além dos limites metropolitanos, no alcance de diferentes regiões do Estado, inaugurando nova etapa de produção do espaço urbanorregional do Vale do Paraíba e Litoral Norte.

Para Silva (2002, p. 33-34), desde então, a metropolização das regiões paulistas se dá em razão da nova economia globalizada, que se propaga na busca de novos mercados e comanda a aceleração das transformações espaciais. A unificação técnico-econômica do território se amplia e as conexões geográficas se multiplicam pelos fluxos de informação e capital. 0 modelo metropolitano de organização socioespacial se torna independente da rede física de cidades e exerce influência sobre os centros urbanos do interior.

Atualmente, a Macrometrópole paulista (Figura 6) compõe-se pelas cinco Regiões Metropolitanas já instituídas: São Paulo, Campinas, Baixada Santista, Vale do Paraíba e Litoral Norte e Sorocaba, além das Aglomerações Urbanas de Jundiaí e Piracicaba, e a Unidade Regional Bragantina.

Nas palavras da EMPLASA (2014), a estruturação da Macrometrópole se deu por meio dos eixos de expansão econômica, a partir da cidade paulistana, e se trata de um fenômeno urbanorregional complexo, envolvendo nova escala de urbanização e integração da rede urbana, em que espaços metropolitanos coexistem com aglomerações urbanas (ao redor de 


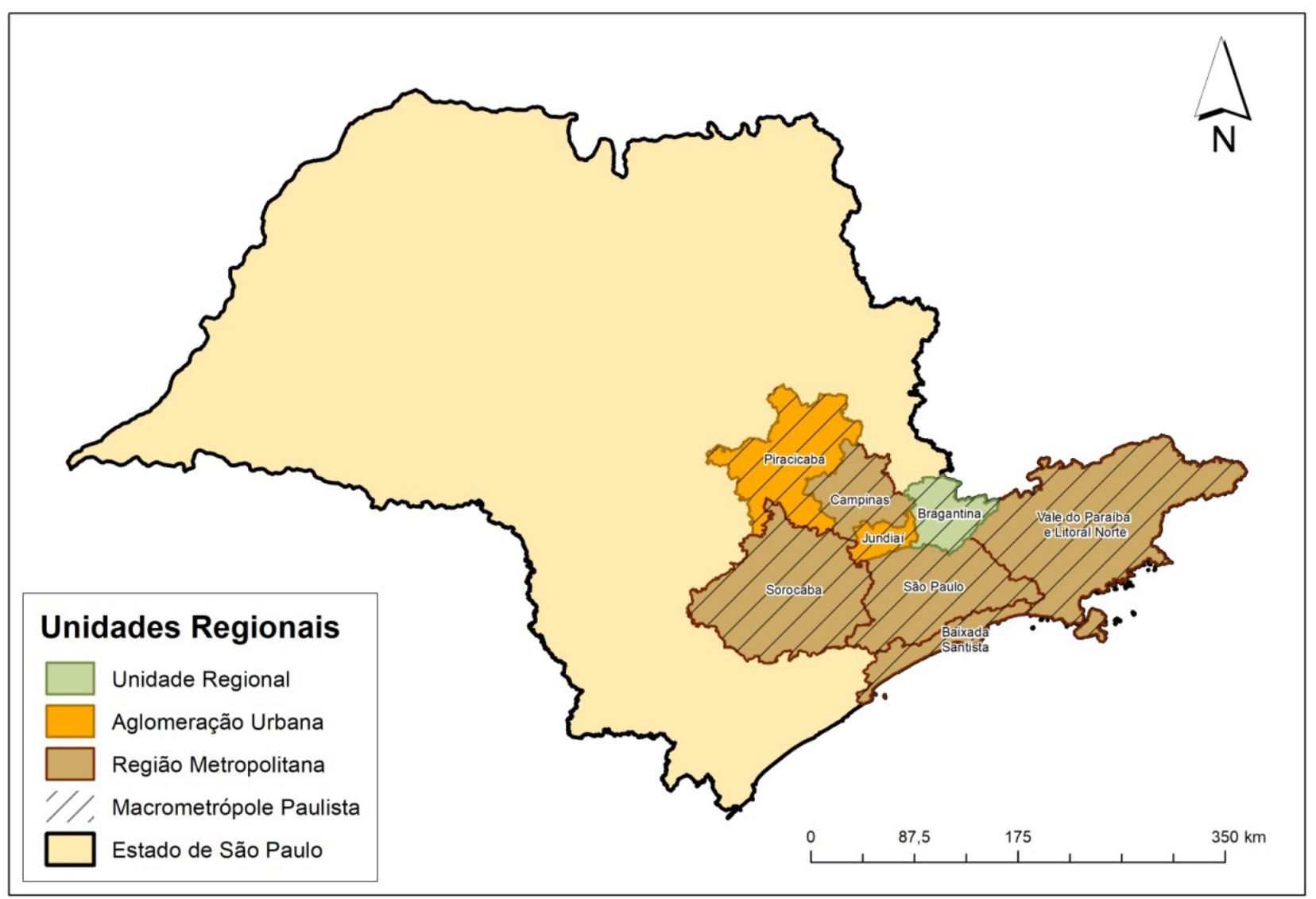

Figura 6 - Macrometrópole paulista

Fonte: Elaboração de Daniel José de Andrade - IBGE (2010); EMPLASA (2016).

núcleos polarizadores) e outros centros urbanos, exercendo influência microrregional.

\section{O Plano de Ação Macrometropolitano}

Alinhando-se alguns conteúdos do PAM a essa compreensão do fenômeno metropolitano, pode-se avaliar se a lógica apresentada do "planejamento para o desenvolvimento" possui reais perspectivas de deixar de ser um plano ortodoxo, suscitando, de fato, outra remodelação - menos desigual e mais participativa — do espaço regional macrometropolitano e do Vale do Paraíba e Litoral Norte.

Em 2014, a EMPLASA publicou o Plano da Macrometrópole Paulista 2013-2040, em quatro volumes, afirmando ter sido concebido em razão de a Macrometrópole constituir um ente físico-espacial e econômico, mas, também, "uma construção geopolítica” (EMPLASA, 2013, p. 22); dessa forma, supostamente, reflete-se um projeto político para reforçar a liderança paulista no cenário nacional e o caráter macroestruturador do espaço metropolitano.

No Volume 1, sobre a política de desenvolvimento da MMP, divulgam-se os objetivos de "[...] promover o desenvolvimento territorial integrado e sustentável, incorporando as dimensões territorial, social e econômica do desenvolvimento" e de "[...] harmonizar políticas públicas integradas com ações focalizadas e espacialmente dirigidas" (EMPLASA, 2014, p. 13). Daí, as três ideias-força do plano: 1. Conectividade territorial e competitividade econômica; 2 . Coesão territorial e urbanização inclusiva, e 3. Governança metropolitana.

Assim se delineia o caminho para o pretenso "futuro desejado por todos" e para ver "reduzidas as iniquidades espaciais e de condições de vida, por meio de distribuição de oportunidades econômicas e da infraestrutura de apoio à produção e atendimento básico da população" (EMPLASA, 2014, p. 14). No mesmo volume, relata-se que "a carteira de projetos (investimentos) 
busca expressar um caráter consensual, pois resulta de consulta pública e validação política" e que se pretende "[...] estabelecer um processo permanente de participação [...] melhorando a governança, mapeando potencialidades e sinergias para o alcance do cenário desejável" (EMPLASA, 2014, p. 15-16).

Já no volume 4 (EMPLASA, 2014, p. 11 a 14), destacam-se, dentre os princípios e diretrizes: 1. Aprofundar a competitividade econômica e a integração funcional; 2. Atrair investimentos e negócios; 3. Ampliar a formação de capital humano e a oferta de educação tecnológica; 4. Modificar a matriz dos deslocamentos pela intermodalidade; 5 . Transformar a MMP no principal hub de transportes e comunicações; 6. Pactuar com diversos agentes sociais; 7. Instituir regulações urbanas orientadas pelas diretrizes do PAM favoráveis à implementação de projetos e ações estruturantes; e 8. Promover a urbanização inclusiva, priorizando a atuação em assentamentos informais.
O PAM se estabelece também por dois tipos de vetores macrometropolitanos de desenvolvimento: os territoriais e os sistêmicos. Definindo-se o vetor macrometropolitano como "um território complexo e dinâmico, de definição física precisa" ou uma estrutura urbana "que realiza a articulação de territórios", tais vetores demonstram relações claras com as ideiasforça do plano. De fato, os vetores territoriais seriam as principais "conexões que desempenham funções em nível intermetropolitano": o vetor da RMSP, o eixo Bandeirantes, o eixo do Vale do Paraíba, o Caminho do Mar, Sorocaba e a Perimetral da MMP (EMPLASA, 2014, p. 22-23) (Figura 7). A inserção do Vale do Paraíba e Litoral Norte se dá em dois vetores territoriais de desenvolvimento:

1. O Vetor do Vale do Paraíba (propriamente dito), abrangendo a ligação São Paulo / São José dos Campos / Taubaté, e três desdobramentos previstos: a) o reforço da centralidade da região,

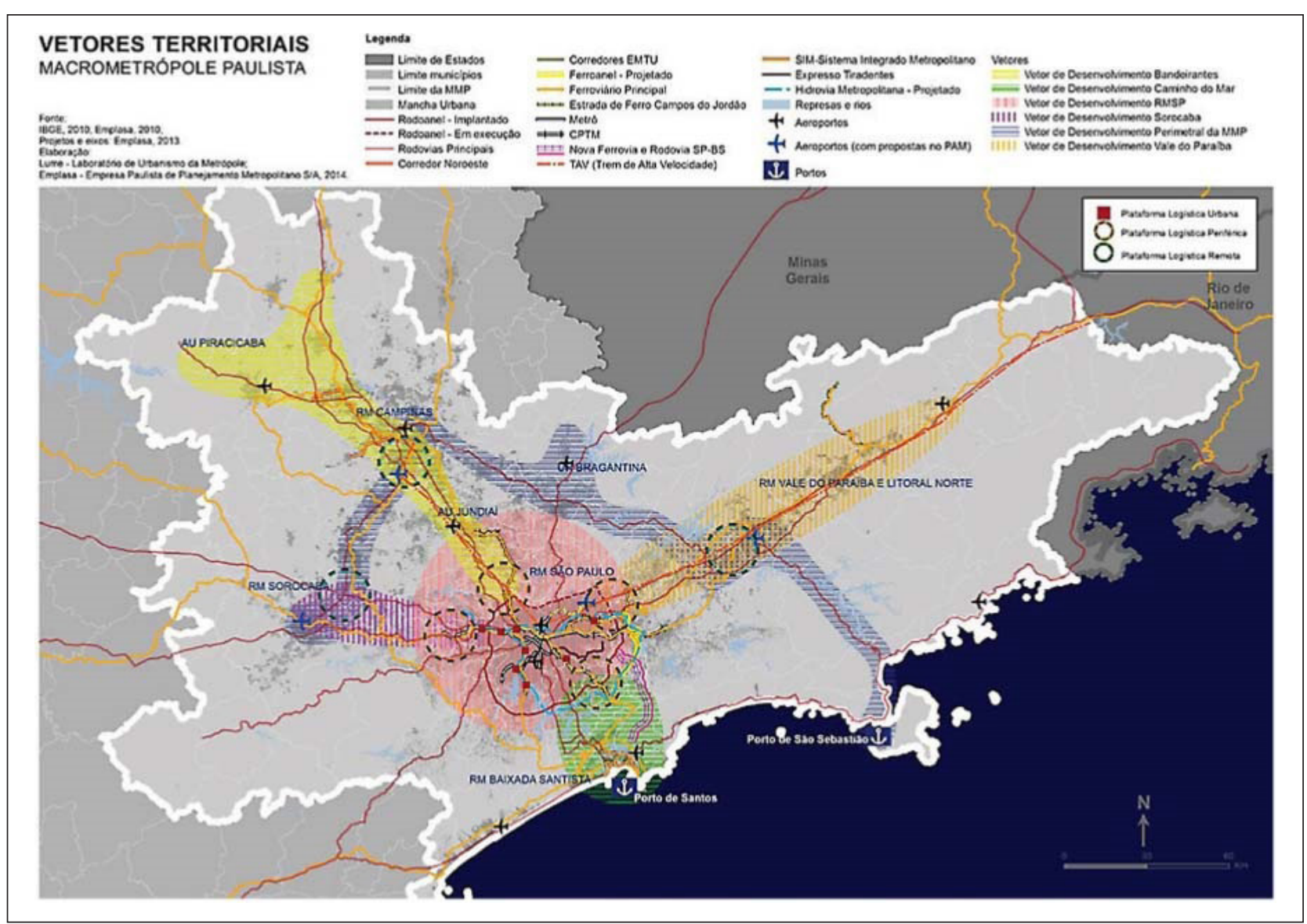

Figura 7 - Vetores territoriais do PAM Fonte: EMPLASA $(2014$, p. 25 , v. 4). 
por meio da melhoria de conexões com Campinas, o interior do Estado de São Paulo e o litoral; entre a capital paulista e Campinas com o Estado do Rio de Janeiro; e, ainda, o Estado de Minas Gerais e o Litoral Norte; b) o adensamento regional das tendências de localização de centros de pesquisa e da produção industrial especializada, e c) a prevenção e superação de problemas urbanos e ambientais derivados do adensamento populacional (EMPLASA, 2014, p. 41-42);

\section{O Vetor de Desenvolvimento Perimetral da} Macrometrópole, correspondendo à estruturação de um "arco" macrometropolitano para propiciar alta conectividade na faixa territorial formada a partir de São Sebastião, passando por São José dos Campos, Jacareí e Campinas até Sorocaba, e que pretende "apoiar os processos de difusão de inovação tecnológica e geração de conhecimento, ampliando a competitividade sistêmica da economia regional e o poder de atração de investimentos", mediante articulação de sistemas multimodais, abrangendo o Porto de São Sebastião, plataformas logísticas (de São José dos Campos, Campinas e Sorocaba), sistemas aeroportuários (São José dos Campos e Viracopos), e eixos rodoviários e ferroviários de passageiros e cargas (EMPLASA, 2014, p. 61).

Quanto aos vetores sistêmicos, definem-se, no PAM, pela "presença de conjuntos naturais ou técnicos", e são pensados "de forma a garantir a competitividade e sustentabilidade": 1. Recursos hídricos e saneamento; 2. Desenvolvimento ambiental; 3. Energia, e 4. Inovação tecnológica (EMPLASA, 2014, p. 22-23).

De modo geral, embora se preconize a internalização da questão ambiental, nota-se a ênfase na busca de superação de desafios ligados à "atratividade econômica sistêmica” (EMPLASA, 2014, v. 4, p. 64). A conciliação de políticas públicas de desenvolvimento regional e ambiental, a proteção de serviços ecossistêmicos que garantam a exploração sustentável, a eficiência energética para a competitividade do território, as estratégias de sustentação de vantagens competitivas da MMP para implantação e desenvolvimento de setores intensivos em tecnologia são diretrizes definidas para ações e projetos que revelam a intenção de investimentos prioritários à sustentabilidade das forças do mercado e do funcionamento de uma economia corporativa e excludente.
Nota-se que a configuração da estratégia de desenvolvimento, por intermédio de eixos territoriais e modais de transporte e logística, sugere fortalecer áreas adensadas por capacidades produtivas e espaços técnico-informacionais consolidados ou potencialmente existentes. Também implica dizer que as perspectivas de equidade e distribuição de renda regional, e investimentos em potencialidades fora dos eixos previstos parecem improváveis. Nesta estratégia, talvez residam, por decorrência, algumas das limitações do PAM na questão do planejamento ambiental, dadas as sobrecargas aos recursos naturais pelo progresso técnico-econômico predatório e pelos impactos da urbanização devoradora de espaços rentáveis, dispersa e precária, e dada a possível prevalência discursiva das preocupações ambientais por sua maior visibilidade política e razão de sobrevivência da lógica hegemônica de grandes agentes econômicos.

Comparativamente, ressalta-se a similaridade de características do PAM e do Plano do Macro-Eixo Paulista, ao priorizarem remodelações ao longo do principal eixo de desenvolvimento do Vale do Paraíba, pautados na premissa da estratégica conexão de estruturas urbanas e mercados entre as principais capitais metropolitanas do país, nos anos 1970: São Paulo e Rio de Janeiro.

\section{Apontamentos para discussões a} caminho da construção do PDUI

Sintetizando-se apontamentos para futuras investigações e debates, três ordens de preocupação serão retratadas. A primeira destas condiz à incerteza quanto às ações territoriais retificadoras propostas pelo PAM. A segunda refere-se à questão das bases teóricas explicitadas nos planos estudados. Por fim, importa destacar, na discussão relativa ao Estatuto da Metrópole, a questão do planejamento regional (metropolitano) e da participação social.

Em recorrência à primeira preocupação, algumas evidências regionais podem ajudar a esclarecer a questão fundamental da necessidade de reversão do quadro estrutural de disparidades sociais e fragmentação espacial da formação socioespacial brasileira, envolvendo basicamente o problema da urbanização desigual (Santos, 1993).

Tal quadro de distorções constituídas historicamente subentende o fato de que parcela importante da 
população regional permanece vivendo em condições precárias de moradia, em áreas com oferta deficiente de serviços públicos e infraestruturas social e urbana, áreas irregulares, ambientalmente sensíveis ou de risco. As ocupações em tais áreas inadequadas ou desprovidas dos benefícios da vida urbana constituem importante componente do déficit habitacional (EMPLASA, 2014, p. 242, v. 2). São José dos Campos, Jacareí, Campos do Jordão, os municípios litorâneos e outros (Figura 8) são exemplos dessa urbanização sem soluções para a questão da função social da cidade e da propriedade.

Desafios imensos se impõem ao poder público e à sociedade. Para seu enfrentamento, certamente será preciso uma forte articulação de diferentes políticas públicas para garantir o pretendido desenvolvimento sustentável, com equidade social e urbanização inclusiva (EMPLASA, 2014, p. 215-216 e 239, v. 2).

Quanto aos aspectos teóricos dos planos estudados, podem-se reconhecer similaridades e diferenças. Desde o final dos anos 1970, com o plano do Macro-Eixo, as decisões de localização e investimentos já eram claramente apontadas, junto aos fatores de produção, como impulsionadores do crescimento econômico e da urbanização regional. A racionalidade econômica da maximização do lucro e as vantagens locacionais comparativas, não se estranha, orientavam ideologicamente o fluxo de capital para áreas com maior potencial de rentabilidade (São Paulo, 1978, p. 10). Além disso, a organização territorial era vista pela ótica teórica das polarizações (São Paulo, 1978, p. 11), associadas à noção de autonomia regional.

Daí aos anos 1990, com as orientações políticas neoliberais, o aumento do grau de competitividade das regiões e lugares para a integração ao mercado global torna-se visão ideológica do modelo do desenvolvimento endógeno e do planejamento estratégico, aplicável à escala urbana ou regional. As novas regiões do mercado tornam-se então mais independentes da regulação do Estado e competitivas (Silva, 2006).

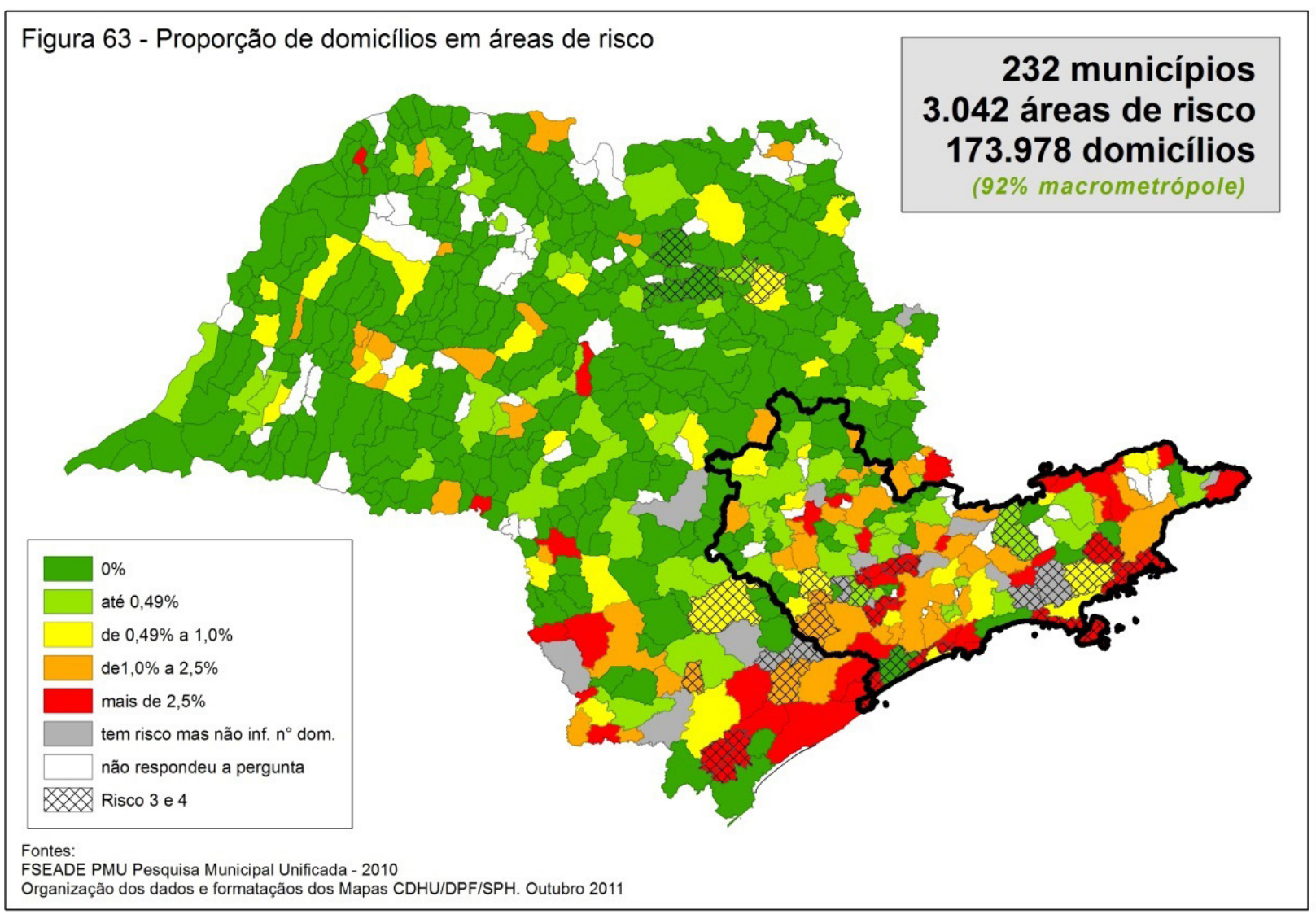

Figura 8 - Proporção de domicílios em áreas de risco Fonte: Adaptado de EMPLASA (2014, p. 242, v. 2). 
Embora o PAM reconheça a assimetria territorial resultante do padrão de desenvolvimento vigente, revela-se bastante afinado com esse pensamento do discurso planificador recente, ao afirmar que "parcela importante da MMP é desprovida de condições de atração de investimentos produtivos", em contrapartida ao fato de que "boa parte da população vive em condições precárias de moradia" (EMPLASA, 2014, p. 22, v. 4).

Além disso, desde o CODIVAP (1971), os planos já assinalavam a tendência de organização territorial por um processo de urbanização conurbada e um sistema urbano de conexões em rede, ao redor de núcleos polarizadores - entendidos como elementos organizacionais para o equilíbrio funcional do território - , refletindo a orientação das teorias da época, da polarização e das regiões funcionais. Em razão do atual caráter disperso, desarticulado e multiescalar da urbanização, as polaridades urbanorregionais tendem a ser ressignificadas, em discussões teóricas recentes, como no PAM, sobre a estratégia de organização regional da policentralidade (EMPLASA, 2014, p. 16-18, v. 2).

A terceira ordem de preocupações relaciona, então, ao processo de construção do PDUI, as exigências do Estatuto da Metrópole e a questão da participação da sociedade civil.

Na reconfiguração do estado democrático de direito, que se edifica após o período militar, a despeito de a CF de 1988 ter consagrado inúmeros dispositivos de garantia de participação da sociedade na formulação e acompanhamento de políticas públicas (graças à emenda de iniciativa popular), a efetivação do marco regulatório da política urbana apenas se deu em 2001, com o Estatuto da Cidade, que explicita pela primeira vez, na história, o conceito de função social da cidade e da propriedade, além de estabelecer o plano diretor participativo como principal instrumento do planejamento urbano.

Com a participação garantida por lei e os instrumentos de promoção da regulação do solo e direito à cidade, vislumbrava-se nova etapa restauradora da crise socioambiental vivida, sobretudo nas metrópoles e cidades médias, em crescimento. Entretanto, os processos participativos, os métodos e os meios para o planejamento, sem enfrentar questões estruturais como o "nó da terra" (Ermínia Maricato), de fato pouco transformaram a realidade socioespacial brasileira.

O fortalecimento do Estado, mais evidente no Brasil nos anos 2003-2009, criou oportunidades para a constituição e os novos marcos regulatórios da perspectiva de planificação em diferentes escalas territoriais, alicerçados por meio de práticas que incluíam consultas à sociedade civil, ainda que sem participação nas decisões.

A consolidação dos enunciados municipalistas evocados na CF de 1988 e a acirrada política de interesses locais (urbanos), além das demandas e pressões do setor imobiliário e da construção civil, também tornaram emergentes questões relativas às funções públicas de interesse comum que extrapolam a municipalidade, mas cujo tratamento se depara com limitações dos arranjos institucionais, políticos e técnicos. Nesse contexto, é retomado, em 2013, o projeto de lei do Estatuto da Metrópole (substitutivo ao de 2004), cujos conceitos de governança interfederativa, função pública de interesse comum, plano de desenvolvimento urbano integrado e obrigatória participação da sociedade no planejamento, controle e acompanhamento das ações, enunciam outras possibilidades para a gestão regional (metropolitana).

Novamente, o dispositivo da participação da sociedade civil organizada se faz presente e, também, mais complexo, tornando-se o exercício do planejamento e da gestão regional, uma vez que demandará organização social na escala regional e sub-regional (metropolitana), em razão da exigência dos PDUIs, com participação social. Todavia, cabe ressaltar a premência de se refletir sobre métodos, concepções, condições, limites e perspectivas da organização da sociedade civil, em especial dos movimentos sociais e de moradia, diante do cenário político, das novas demandas urbanas contemporâneas, da aparição de novos movimentos e necessidades mais pontuais e pragmáticas, com agendas não necessariamente orientadas pelo horizonte de médio e longo prazo. A rua passou a ser o lugar de manifestações, mas nem sempre de política com ideologias definidas.

\section{Conclusão}

Considera-se, então, mais uma vez, que a localização estratégica da RMVPLN parece orientar a visão planificadora enquanto estrutura territorial instrumental para garantir a reprodução ampliada do modelo neoliberal de aproveitamento máximo das diferentes vantagens locacionais oferecidas. 0 reforço dessa lógica integradora de interesses hegemônicos, mas dissociada das reais demandas do desenvolvimento urbanorregional, poderá, muito 
provavelmente, acentuar ainda mais a desigual composição das realidades sub-regionais da RMVPLN.

É notório, de fato, que a coesão territorial pretendida pelo PAM tenderia a se consolidar por um desenvolvimento que busca converter "as diferenças territoriais em vantagens competitivas", para garantir a sustentabilidade do status quo de um sistema político que procura estabelecer sua carteira de projetos e a promoção de fóruns apenas para legitimar pactos negociados, bem como as regulações necessárias para compatibilizar planos, projetos e ações regionais com as diretrizes macrometropolitanas. A implantação das condições territoriais especiais no "locus prioritário" seria autorizada para "garantir competitividade às empresas que ali estejam ou que venham a se instalar" (EMPLASA, 2014, p. 21, 24 e 61, v. 4).

Questiona-se, de fato, se a utopia macrometropolitana será viável, pois supõe a gestão complicada de uma megaestrutura socioespacial ainda mais complexa que a das regiões metropolitanas, desarticulada de um projeto de nação e sem a força endógena de articulações entre governos, sociedades ou populações locais. Eis os desafios gerais referentes à governança metropolitana, à cooperação interfederativa e à ampla participação social.

A construção desse processo de planificação regional demandará revisitar a questão indissociável das ações integradas. Questiona-se então se será possível conciliar a lógica tão propagada da competitividade com a perspectiva de real cooperação, em torno do objetivo de um desenvolvimento regional com mais equidade social. Em outros termos, e com a finalidade de redução progressiva das desigualdades, será preciso identificar quais objetivos comuns e prioritários poderão de fato engendrar novas sinergias de cooperação, sem que a superação dos desafios inerentes aos desenvolvimentos locais deixe de ser balizada e cada lugar possa assumir, de fato, seu valor diferencial e seu potencial cooperativo no contexto regional que o engloba.

Nessa tendência inerente à atual globalização, a opção pelo reconhecimento de forças sociais singulares e ações que as potencializem, gerando um desenvolvimento fundado na sociodiversidade regional e local, parece fazer sentido na perspectiva da construção de um destino, de fato, pactuado socialmente para a região e suas localidades. A questão advém do papel das sinergias entre Estado e sociedade no processo de regulação socioterritorial, pois há, sem dúvida, o risco da inibição do desenvolvimento de localidades sem vantagens comparativas e, por isso, de reforço das distorções históricas, caso essa afinação entre ações do poder público e dos demais agentes seja exclusivista, fraca ou inexistente.

$\mathrm{Na}$ estrutura matriz do planejamento e do desenvolvimento, estabelecer consensos em torno de projetos regionais ou locais de interesse comum ou prioritário é correlato à construção de identidade e consciência regional (Silva, 2006), sem o que as possibilidades de participação, cooperação e ações integradas se tornam ainda mais remotas.

\section{Referências}

Associação Pró-Gestão das Águas da Bacia Hidrográfica do Rio Paraíba do Sul - AGEVAP. (2007). Plano de Recursos Hídricos da Bacia do Rio Paraíba do Sul - Resumo. Gestão Integrada das Águas e Florestas da Bacia do Rio Paraíba do Sul. Resende: Ceivap, Agevap, Fundação COPPETEC, Laboratório de Hidrologia e Estudos de Meio Ambiente. Relatório final.

Baptista, C. D. (1940). Aspectos do Vale do Paraíba e do seu reerguimento no Governo Adhemar de Barros. Taubaté: Secretaria de Agricultura, Indústria e Comércio, Instituto Agronômico do Estado de São Paulo.

Bicudo, M. M. (2009). Padrões e singularidades. In Reis, N. G., Fo. (Ed.), Sobre dispersão urbana (1. ed., p. 247-257). São Paulo: Via das Artes.

Brasil. (1969). Emenda Constitucional no 1, de 17 de outubro de 1969. Brasília: Diário Oficial da União. Recuperado em 19 de maio de 2017, de http://www.planalto.gov.br/ccivil_03/ Constituicao/Emendas/Emc_anterior1988/emc01-69.htm

Brasil. (1973, 8 de julho). Lei Complementar no 14, de 8 de junho de 1973. Brasília: Diário Oficial da União. Recuperado em 2 de março de 2017, de http://www.planalto.gov.br/ ccivil_03/leis/LCP/Lcp14.htm

Brasil. (1975). Lei Complementar no 75, de 20 de maio de 1993. Brasília: Diário Oficial da União. Recuperado em 19 de maio de 2017, de http://www.planalto.gov.br/ccivil_03/ leis/lcp/lcp75.htm

Brasil. (1988a). Constituição da República Federativa do Brasil de 1988. Brasília: Diário Oficial da União. Recuperado em 19 de maio de 2017, de http://www.planalto.gov.br/ ccivil_03/constituicao/constituicao.htm 
Brasil. (1988b). Lei no 7661, de 16 de maio de 1988. Brasília: Diário Oficial da União. Recuperado em 19 de maio de 2017, de http://www.planalto.gov.br/ccivil_03/leis/L7661.htm Brasil. (1997). Plano Nacional de Recursos Hídricos. Brasília: Departamento Nacional de Águas e Energia Elétrica. Recuperado em 2 de março de 2017, de http://www. planalto.gov.br/ccivil_03/leis/L9433.htm

Brasil. (2001, 10 de julho). Lei Federal no 10.257, de 10 de julho de 2001. Estatuto da Cidade. Brasília: Diário Oficial da União. Recuperado em 2 de março de 2017, de http:// www.planalto.gov.br/ccivil_03/leis/LEIS_2001/L10257.htm

Brasil. (2015). Lei no 13.089, de 12 de janeiro de 2015. Institui o Estatuto da Metrópole. Brasília: Diário Oficial da União. Recuperado em 16 de outubro de 2015, de http:// www.camara.gov.br

Coelho, L. T. K. F. (1998). Estudo Analítico das Propostas para o Desenvolvimento Regional do Vale do Paraíba-SP, de 1971 a 1991 (Dissertação de mestrado). Instituto de Pesquisa e Desenvolvimento, Universidade do Vale do Paraíba, São José dos Campos.

Comitê Executivo de Estudos Integrados da Bacia Hidrográfica do Rio Paraiba do Sul - CEEIVAP. (1979). Diretrizes de ordenamento do Uso do Solo: Macrozoneamento da Bacia Hidrográfica do Rio Paraíba do Sul. Projeto Gerencial 0003/79. São Paulo.

Consórcio de Desenvolvimento do Vale do Paraíba - CODIVAP. (1971). Caracterização do conhecimento existente sobre a região do Vale do Paraíba. Pindamonhangaba.

Departamento Nacional de Infraestrutura e Transporte - DNIT. (2013). Recuperado em 19 de maio de 2017, de http://www.dnit.gov.br/

Empresa Paulista de Planejamento Metropolitano EMPLASA. (2013). PAM: Macrometrópole Paulista Leitura do Território. São Paulo: EMPLASA. Recuperado em 13 de novembro de 2014, de http://www.sinaenco.com.br/ downloads/Rovena.pdf

Empresa Paulista de Planejamento Metropolitano - EMPLASA. (2014). PAM: Plano de Ação da Macrometrópole Paulista 2013-2040: política de desenvolvimento da macrometrópole (4 v.). São Paulo: EMPLASA.

Empresa Paulista de Planejamento Metropolitano - EMPLASA. (2016). São Paulo: EMPLASA. Recuperado em 19 de maio de 2017, de https://www.emplasa.sp.gov.br/RMRP
Instituto Brasileiro de Geografia e Estatística - IBGE. (2010). Recuperado em 19 de maio de 2017, de http:// www.ibge.gov.br/home/

Instituto Nacional de Pesquisas Espaciais - INPE. (1992). Macrozoneamento da Região do Vale do Paraíba e Litoral Norte do Estado de São Paulo. São José dos Campos: Instituto Nacional de Pesquisas Espaciais.

Maricato, E. (2000). As idéias fora do lugar e o lugar fora das idéias: planejamento urbano no Brasil. In Arantes, O., Vainer, C., \& Maricato, E. A cidade do pensamento único: desmanchando consensos (p. 121-192). Petrópolis: Vozes.

Meyer, R. M. P., Grostein, M. D., \& Biderman, C. (2004). São Paulo metrópole. São Paulo: Editora da Universidade de São Paulo, Imprensa Oficial do Estado de São Paulo.

Muller, N. L. (1969). O fato urbano na Bacia do Rio Paraíba - SP. Rio de Janeiro: IBGE.

Penha, G. (1991, 28 de outubro). Metrópole cresce em outras três direções (Geral, p. 3). São Paulo: O Estado de São Paulo.

Reschilian, P. R., \& Uehara, A. Y. (2015). Arranjos institucionais no Brasil: paradoxos de riqueza e déficit social: o estudo da dimensão territorial para o planejamento e a Macrometrópole paulista. In Anais do XVI Encontro Nacional da Associação Nacional de Pós-graduação e Pesquisa em Planejamento Urbano e Regional. Belo Horizonte: ANPUR.

Ronca, J. L. C., \& Vitale, S. P. S. M. (2004). Caminhos para a gestão integrada do território no Vale do Paraíba de 1950 a 2004. Exacta, 2, 133-149.

Santos, M. (1993). A urbanização brasileira. São Paulo: Hucitec.

Santos, M. (2000). Por uma outra globalização: do pensamento único à consciência universal. Rio de Janeiro: Record.

São Paulo. Governo do Estado. (1964). Lei no 8.208, de 8 de julho de 1964. São Paulo: Diário Oficial do Estado. Recuperado em 2 de março de 2017, de http://www. al.sp.gov.br/repositorio/legislacao/lei/1964/lei-820808.07.1964.html

São Paulo. (1970). Decreto no ${ }^{\circ}$ 52.548. Reorganiza a Secretaria de Economia e Planejamento e da providências correlatas. São Paulo: Diário Oficial do Estado. Recuperado em 19 de maio de 2017, de http://www.al.sp.gov.br/repositorio/ legislacao/decreto/1970/decreto-52548-29.10.1970.html

São Paulo. Governo do Estado. (1974). Lei complementar $n^{\circ}$ 94, de 29 de maio de 1974. São Paulo: Diário Oficial do 
Estado. Recuperado em 2 de março de 2017, de http://www. al.sp.gov.br/repositorio/legislacao/lei.complementar/1974/ lei.complementar-94-29.05.1974.html

São Paulo. Governo do Estado. (1978). Plano regional do macro-eixo paulista. São Paulo: Secretaria de Economia e Planejamento-Coordenadoria de Ação Regional.

São Paulo. (2004). Decreto Estadual no 49.215. Dispõe sobre o Zoneamento Ecológico-Econômico do Setor do Litoral Norte, prevê usos e atividades para as diferentes zonas, estabelece diretrizes, metas ambientais e sócio-econômicas e dá outras providências. São Paulo: Diário Oficial do Estado. Recuperado em 19 de maio de 2017, de http:// www.al.sp.gov.br/repositorio/legislacao/decreto/2004/ decreto-49215-07.12.2004.html

São Paulo. Governo do Estado. (2012). Lei Complementar $n^{\circ}$ 1.166, de 09 de janeiro de 2012. São Paulo: Diário Oficial do Estado. Recuperado em 2 de março de 2017, de http://www. al.sp.gov.br/repositorio/legislacao/lei.complementar/2012/ lei.complementar-1166-09.01.2012.html

São Paulo. Governo do Estado. (2015). Lei Complementar $n^{\circ}$ 1.258, de 12 de janeiro de 2015. São Paulo: Diário Oficial do Estado. Recuperado em 2 de março de 2017, de http://www. al.sp.gov.br/repositorio/legislacao/lei.complementar/2015/ lei.complementar-1258-12.01.2015.html

Silva, M. L., No. (1990). Extensores urbanos: o caso da cidade de São Paulo (Dissertação de mestrado). Faculdade de Arquitetura e Urbanismo, Universidade de São Paulo, São Paulo.

Silva, M. L., No. (2002). A interação técnico-econômica do território paulista. In Anais do II Encontro Brasileiro de Estudos Regionais e Urbanos. São Paulo: Associação Brasileira de Estudos Regionais.

Silva, M. L., No. (2006). Novas regiões, outros desafios: a regionalização do novo mercado em São Paulo e suas implicações no planejamento urbano-regional. Cadernos IPPUR, 20(1), 49-75.

Silva, M. L., No., Azzoni, C. R., \& Hoffmann, J. C. (2002). Regionalização do Estado de São Paulo: para onde vai? São Paulo: Secretaria de Economia e Planejamento do Estado de São Paulo. Relatório de pesquisa.

Recebido: Ago. 24, 2016

Aprovado: Maio 08, 2017 